\section{SOVIET SCIENCE}

\section{Polluted Rivers}

from our Soviet Correspondent

THE recent industrial expansion in the Ural area has, inevitably, led to a major pollution problem in the Volga and Ural rivers. The problem has now reached such proportions that antipollution measures for these rivers became the subject matter of a recent resolution of the Soviet Government, and became headline news in Pravda.

Starting with a minor note of selfcongratulation, the resolution states that in the past five years, 670 purification plants have been installed on these rivers, with a total capacity of over 3 million $\mathrm{m}^{3}$ a day. Many manufacturing plants have also introduced water-free processes or waste-recovery units.

The capacity of recirculatory water systems has increased to some 70 million $\mathrm{m}^{3}$ a day, and the discharge into the rivers of such pollutants as petroleum products, copper, zinc and phenols has been "considerably" reduced. Nevertheless, the very wording of this claim seems to suggest that the amount of such pollutants entering the rivers is still by no means negligible.

Immediate plans, under the new resolution, also underline the magnitude of the problem. 421 major manufacturing enterprises are to be equipped with purification plants by 1975 at a cost of 700 million roubles. Another $300 \mathrm{mil}$ lion roubles are allotted to urban sewage and purification plants in 15 towns on the Volga and its tributary, the Kama. Looking forward to the next 5 year plan (1976-80) it is claimed that by the end of the decade discharge of unpurified industrial wastes and sewage into these rivers will have been "totally stopped".

As an immediate anti-pollution measure, the Ministry of Fisheries and Ministry of River Navigation of the USSR are to equip the ships using the Volga and Ural rivers with "devices and systems for collecting waters polluted by urban wastes and bilges". At the same time collecting devices for petroleum wastes and other liquid and solid pollutants are to be installed in the river ports and shipping basins of these rivers. The resolution, however, does not indicate the nature of the devices to be used, either for the ships or the port installations.

The Ministry of Irrigation and Water Economy and the industrial ministries are also to undertake projects aimed, not only at cutting pollution of the Volga, but also at eliminating wastage of the river water by industry. Although the Volga is the largest river of the Soviet Union, it is now barely able to maintain a sufficient water supply for all the demands made upon it by indus- try and irrigation. Thus the plans, first envisaged in the 1930 s, of diverting the waters of the north-flowing Siberian rivers to feed the Volga and its tributaries are now being implemented. Since the major drought of the 1930s, when the annual influx of water from the Volga into the Caspian fell from 250 to $170-190 \mathrm{~km}^{3}$ per year, the waterlevel of the Caspian has been falling and the salinity rising with a consequent threat to the caviare fisheries, already threatened by the expansion of offshore oil-drilling.

\section{METRICATION}

\section{To Keep the Ball Rolling}

THE impetus must be restored to the changeover to metric units in Britain or the national economy and individual businesses will be faced with uncertainties which could be "seriously damaging" according to the Metrication Board's third report published last week (Report of the Metrication Board, 1971, HMSO, £0.90). The report goes on "only the government can give the positive lead which is essential to restore confidence and recover the buoyancy and energy which is necessary if metrication is to resume its advance on a broad front as a coherent national policy".

But in spite of the hiatus caused by the non-appearance of the govern-

\section{LONDON ZOO \\ New Home for Primaies}

Wirt the opening last week of the Michael Sobell pavilions for apes and monkeys, named after its benefactor, at the Zoological Society of London's gardens in Regent's Park, a new high standard for the husbandry and exhibition of these animals in urban zoos is set. The old scene of lonely animals in barred, bare cages is swept away and the zoo now offers a select thirteen species of the larger monkeys and apes the chance of domesticity and family life, and the next best thing to trees.

The species of primate which have been chosen to spend their days in such luxury include the mandrill, pig tailed macaque, colubus, orang utan, chimpanzee and lowland gorilla. These animals are housed in family groups or colonies in five pavilions or den blocks and each animal has the new found advantage of being able to move freely between its inside den and an outside enclosure.

The orang-utan shown here is taking exercise on the tubular steel space frame which has been fitted in each outside enclosure to provide the animals with horizontal routes high above ground so ment's white paper on metrication until February 1972, the metrication board reports that progress in 1971 was "broadly satisfactory". The construction industry kept to its timetable of complete metrication by 1973 , but the rate of change in the engineering industry was not as rapid as in previous years. Progress in the fuel and power industries continued to be satisfactory, and the metrication of overseas freight went ahead well, although inland freight made fewer changes. The board also feels that the major part of the work of the Steering Committee for Education and Industrial Training has been accomplished.

In conclusion the board says that "it continues to be our view that, given a firm lead by the government, Britain can substantially accomplish the changeover to metric by $1975 "$.

Lord Ritchie-Calder, retiring chairman of the Metrication Board, said last week that the white paper had removed uncertainties about the government's metrication policy and had defined the task ahead. Lord Orr-Ewing, the board's new chairman, said that the rate of metric change must be speeded up; if the United States metric conversion bill becomes law, 99 per cent of Britain's exports and 99 per cent of world trade will be with countries that have chosen metric. "It is unthinkable that Britain should lag behind and become an isolated imperial island in a totally metric sea."

that arboreal species can move about as they would in trees in their natural habitat. The animals can also climb on the tensioned wire mesh which surrounds the enclosures-and which also keeps the public at bay--and there are more climbing structures inside the dens. Spectators are clearly going to enjoy the new pavilions. Time will tell whether the arrangements will encourage the animals to breed.

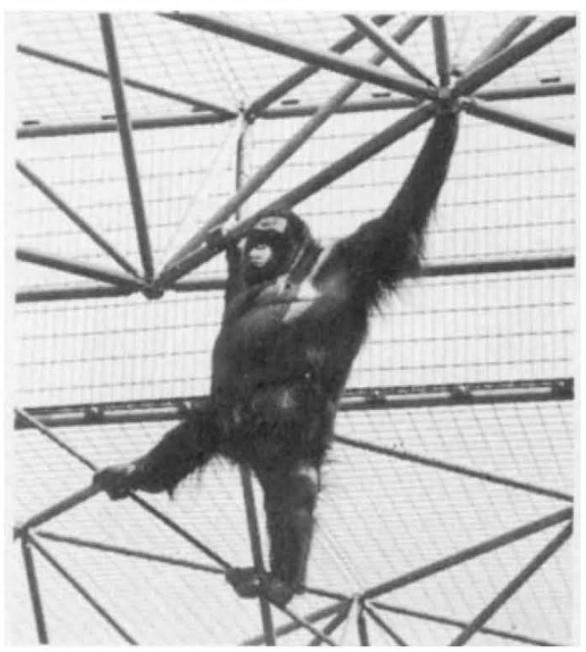

Orang-utan in the new Michael Sobell pavilions for apes and monkeys at the London zoo. 